\title{
Mustafapaşa (Sinasos) Duvar Resimlerinde Sıradışı Konular ve Georgios Iordanidis
}

\author{
Extraordinary Themes in the Wall Paintings of Mustafapaşa (Sinasos) \\ and the Painter Georgios Iordanidis
}

\begin{abstract}
Yıldıray ÖZBEK*
$\ddot{O} z$ : Kapadokya Bölgesi'nde yer alan ve günümüzde Mustafapaşa adıyla bilinen Sinasos, 19. yüzyılda sakinlerinin 3/4'ü Rumlardan oluşan bir kasabadır. 19. yüzyılın ikinci yarısında kasabadan komşu şehirlere ve özellikle İstanbul'a çalışmaya gidip, kendi işlerini kurup servet edinenler, kasabalarında gösterişli konaklar inşa ettirmişlerdir. Konakların çoğunda konu bakımından imparatorluğun diğer bölgelerindeki örneklerden farklılık gösteren duvar resimleri yer almaktadır. Çoğunda sanatçı imzasına rastlanan bu resimlerde Apelles'e atfedilen Hellenistik bir öykünün yanı sıra, 19. yüzyıl Fransız ressamlarından Pierre Auguste Cot'un tablolarından birinin kopyasını ve 17. yüzyıl Avrupa el yazmalarında örnekleri görülen "Yaşam Merdiveni" konusunun ele alındığı görülmektedir. Bu makale bahsedilen resimlerin nasıl bir sosyo-kültürel zeminde ortaya çıktığını ve sanatçı olarak Georgios Iordanidis’i tartışacaktır.
\end{abstract}

Anahtar sözcükler: Apelles, Duvar resmi, Kapadokya, Mustafapaşa (Sinasos), Iordanidis

\begin{abstract}
The town of Sinasos, in the region of Cappadocia, is today called Mustafapaşa, and it was a town with three quarters of its resident population Greeks in the 19th century. In the second half of the 19th century, many of the people of Sinasos who went to work in neighboring cities and particularly in Istanbul became wealthy, and built flamboyant houses in their town. Wall paintings that differ from examples in other regions of the Empire, in terms of the themes that were depicted, were painted on the walls of the most of these houses. Most of these paintings have the painter's signature, as well as a Hellenistic story referring to Apelles; while there is a painting on the theme of "the Cycle of Life by the $19^{\text {th }}$ century French painter Pierre Auguste Cote, earlier examples of which can be found in $17^{\text {th }}$ century manuscript depictions. This article is concerned with the social and cultural background of these paintings, and with the artist, Georgias Iordanidis.
\end{abstract}

Keywords: Apelles, Wall painting, Cappadocia, Mustafapaşa (Sinasos), Iordanidis

\section{Giriş}

Osmanlı resim sanatı, 18. yüzyıla kadar daha çok elyazması kitapların metinlerini anlatmak amacıyla yapılmış minyatürlerden ibaretken, 18. yüzyılın ikinci yarısından itibaren "duvar resmi" olarak tanımlanacak yeni bir tarz ortaya çıkmıştır. Duvar resimleri, duvar üzerine çekilmiş alçı sıva veya kurşun karbonat içerikli, hava etkilerine dayanıklı beyaz bir boya türü olan "üstübeç" (isfidac) üzerine ya da ahşap üstüne suyla karıştırılmış boyalarla yapılmıştır (Arık 1999, 423; Renda 2002, 268). 19. yüzyılda sıva veya ahşap malzeme üzerine yapılanlar-

\footnotetext{
* Prof. Dr., Akdeniz Üniversitesi, Edebiyat Fakültesi, Sanat Tarihi Bölümü, Antalya. yozbek@akdeniz.edu.tr Rumca kitabeleri okuma zahmetinde bulunan Prof. Dr. Murat Arslan ve Sevcan Özkurt’a ne kadar teşekkür etsem azdır.
} 
dan başka, ahşap tavanlar veya duvar kaplama tahtaları üzerine gerilmiş deri ya da keten bezi gibi malzemelere de yapılmış örnekler olduğu bilinmektedir (Tekinalp 2002, 444).

Duvar resimlerinin ilk örnekleri başkent İstanbul'da, Topkapı Sarayı Harem Dairesi'nde ve çeşitli konak, yalı vb. sivil mimarlık eserlerinde, daha çok insana huzur veren doğa manzaraları ile bir kısmı fotoğraftan çalışılmış (Tekinalp 2010, 291-299) gerçek veya hayali kent tasvirleri şeklinde ortaya çıkmıştır. Topkapı Sarayı'nda bulunan duvar resimlerinin en erken örneklerine I. Abdülhamid'in saltanatı sirasında (1774-1789) rastlansa da, 1750 tarihli Bebek Kavafyan Konağ 1 tavan eteklerinde görülen çeşme ve bahçeli köşk resimleri (Atasoy 1976, 23-43; Arslan 2014), yeni resim anlayışının saray dışında ve hatta saraydan önce beğenilip benimsendiğine işaret edebilir. Topkapı Sarayı'nda bulunan erken örneklerde, belirgin özellikleriyle hemen tanınabilecek bir cami veya türbe gibi mimari konulu manzaralardan ziyade Boğaziçi ve Haliç'i çağrıştıran manzaraların işlendiği, fiskiyeli havuzlar ve düzenli çiçek bahçelerine açılan sahil sarayların sevilen birer tema olarak sık sık tekrarlandığı vurgulanır (Renda 2003, 936). Bazı örneklerde $\mathrm{S}$ ve C kıvrımlarından oluşan kartuşlar içinde yapı kalıntılarının da betimlenmiş olduğu görülür (Arık 1999, 424). Gerek Topkapı Sarayı Harem Dairesi'nde, gerekse de İstanbul'da bulunan kimi yalı veya konaklarda tavan eteğindeki dar şeritlerde ya da geniş panolarda yer alan duvar resimleri, konu itibariyle manzaralar içermekle birlikte, nadiren figürlü ve konulu örneklerin de bulunduğu tarihsel kaynaklardan öğrenilmektedir. Örneğin 18. yüzyılda İstanbul'a gelen seyyah Abbé Toderini'nin Kaptan Paşa'nın Levent'teki çiftlik evinde duvara yapılmış büyük bir savaş resmi gördüğünü kaydettiği ifade edilmektedir (Renda 1977, 108-109).

Duvar resimleri, 18. yüzyılın sonları, 19. yüzyılın ilk çeyreğinden itibaren imparatorluğun Anadolu, Balkanlar, Ortadoğu gibi tüm bölgelerinde beğeniyle tatbik edilir. Taşra örnekleri, başkenttekilerden farklı olarak ev, konak gibi sivil yapıların yanı sıra cami, türbe, şadırvan gibi dinî yapılarda da görülür. Çoğunlukla İstanbul, Mekke, Medine gibi gerçek kent tasvirleriyle birlikte doğa manzaralarını da içeren taşra örneklerinde nadiren figürlü anlatımlarla karşılaşılır. Yozgat Nizamoğlu Konağında (1871) Eski Ahit’ten öyküler içeren duvar resimleri (Arık 1988, 51) istisna kabul edilirse, figürlü tasvirlerin büyük çoğunluğu bir hikâyeyi anlatmaktan uzaktır.

Günümüzde daha çok Nevşehir, Niğde, Aksaray ve Kayseri gibi merkezleri içeren Kapadokya Bölgesi'nde de imparatorluğun diğer merkezlerinde olduğu gibi duvar resimleriyle karş1laş1lır. Bölge içinde Kayseri, Ürgüp, Göreme gibi kent ve kasabalardaki örneklerden hareketle yapılmış çalışmalarda İstanbul, Edirne gibi gerçek kent tasvirlerinin yanı sıra, hayali manzaralar ve birkaç örnekte gerçek veya denizkızı gibi fantastik figürlü betimlemeler görüldüğü ileri sürülür (Renda 1986, 103-132; Özbek 2011, 209-219; 2014, 215-230). Resimlerin hiç birinde sanatçı adına rastlanmaz. Öte yandan makalede bahsedeceğim duvar resminin bulunduğu Sinasos kasabasındaki örnekler, teknik bakımdan diğerlerinden farklılık göstermemekle birlikte, hem konu hem de sanatçı isimleri içermesi bakımından özgün niteliktedirler. Daha önce kültür tarihi yönünden detaylıca tartışılmayan duvar resmi ve sanatçısından hareketle bu küçük Kapadokya kasabasının özellikle 19. yüzyılda yaşadığı değişimi tartışmak makalenin konusunu oluşturmaktadır.

\section{Duvar Resimleri}

Makalede tanıtıp tartışacağım duvar resmi Sinasos'ta yakın zamana kadar Canseverler Konağı olarak bilinen ancak, günümüzde Kapadokya Meslek Yüksekokulu'nun kullanımında olan ve 1924 Nüfus Mübadelesi'yle bölgeden ayrılmış Rumlardan Zafira Faslaha'ya ait konakta yer almaktadır. Avluya açılan mekânlardan birinin kemer kilit taşı üzerinde yer alan ve kısmen tahrip olan yazıtta görülen 64 sayısından hareketle konağın 1864 yılında inşa edildiği kabul 
edilebilir. Duvar resmi, konağın avluya açılan ve doğu-batı doğrultuda dikdörtgen plânlı, sivri tonoz örtülü köşk odası veya kabul odası olarak tanımlanan mekânında, girişin karşısında, doğu cephede pencere açıklıkları ile tonoz başlangıcı arasındaki duvar yüzeyine yapılmıştır. Resim, tonozun eğrisine göre biçimlenen ve yanlardan akanthus'lu kıvrımdallarla çerçevelenmiş bir yüzeye işlenmiştir (Fig 1).

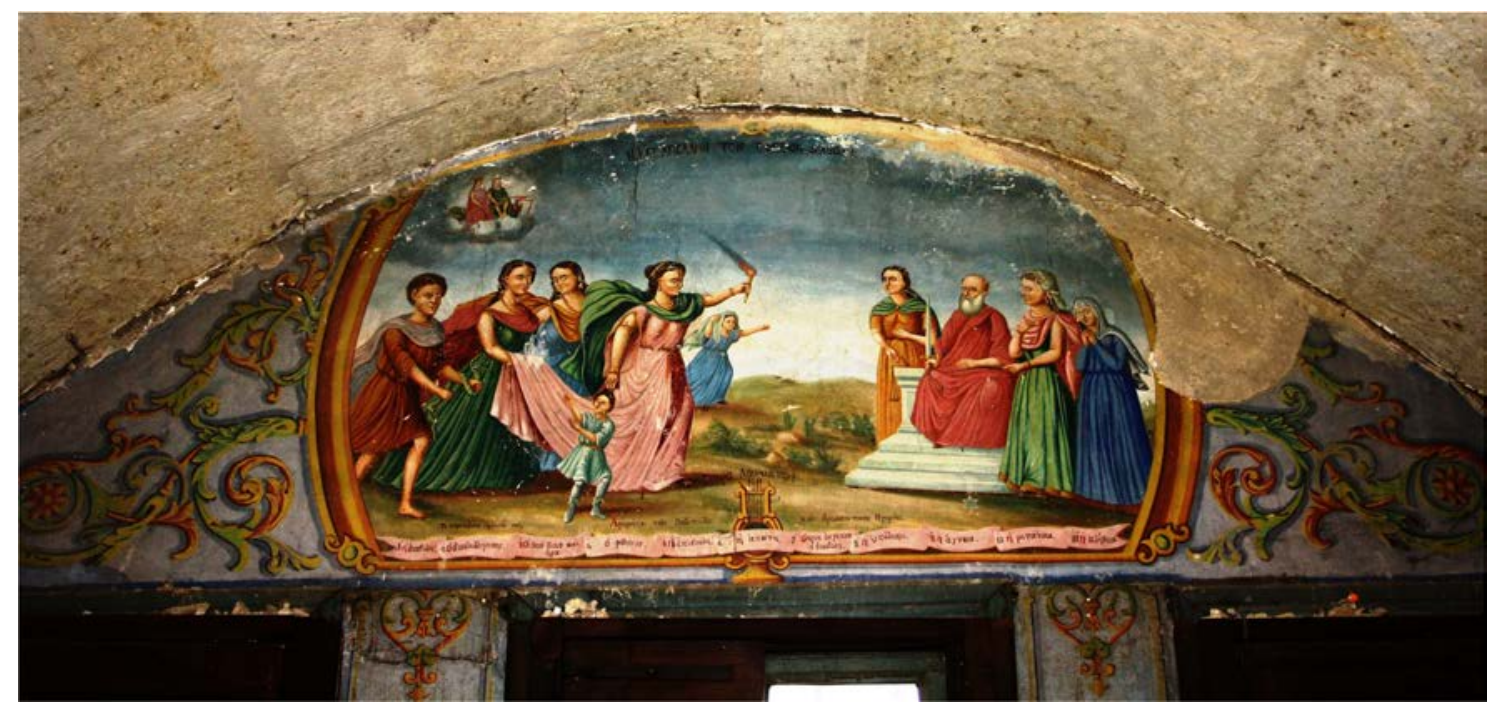

Fig 1. Mustafapaşa (Sinasos), Apelles'e Ifttira Atılması, Duvar Resmi. Canseverler Konağ1.

Resmin üzerinde, tonoz başlangıç seviyesinde yer alan ve Hellence yazılmış olan "H KAT

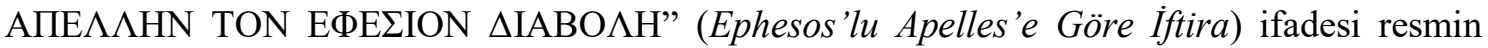
konusunu açıklamaktadır. Resmin alt bölümündeki yazı kuşaklarından en üsttekinde Hellence

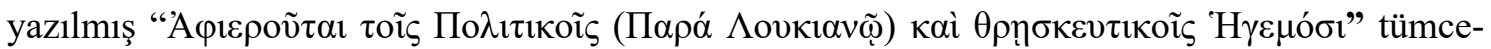
sinden, 'Lucianus'tan alıntılanan bu sahnenin siyasi ve dini liderlere ithaf edildiği' ögrenil-

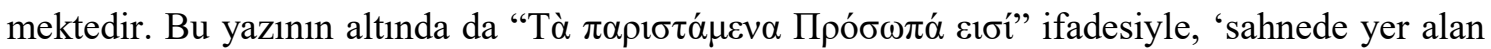
karakterler' tanımlanmış, en alttaki yazı kuşağında da resimde numaralandırılmış figürlerin simgeledikleri kavramlar açıklanmıştır. Kompozisyonda ağırlıklı olarak iki figür grubundan söz edilebilir. Resmin sağ tarafında biri oturmuş, üçü ayakta betimlenmiş dört figür görülmektedir (Fig 2). Figürlerden mermerden üç basamaklı bir tahtta oturanı, sağ eliyle bir kılıcı dik tutar pozisyonda resmedilmiş olup, beyaz sakallı ve abartılı şekilde büyük kulaklı yaşlı bir kişi olarak betimlenmiştir. Oturuş biçiminin ve elbise kıvrımlarının yansıtılmasında, 1şık-gölge ve renk tonlamalarında başarılı bir anlatımdan söz edilebilir. Giysinin ucunda gösterilen 7 rakamı, aşağı-

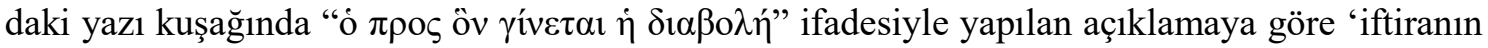
açıklandığı kişiyi' işaret etmektedir. Oturan figürün sağında, ayakta durur pozisyonda, sağ elinde adaleti simgeleyen bir terazi tutan kadın figürü yer alır. Kadın, omzundan arkaya atılmış yeşil renk pelerini, oksit sarısı renkli elbisesiyle ve şaşkınlık içeren bir yüz ifadesiyle, karşısındaki gruba bakar biçimde resmedilmiştir. Elbisesinin ucunda 9 rakamıyla tanımlanan figür, aşağıdaki yazı kuşağındaki " $\eta \dot{\gamma}$ ö $v o 1 \alpha$ " ifadesine göre 'cehaleti' simgelemektedir. Oturan figürün solundaki iki kadın figüründen 8 numarayla tanımlanan ve "í vं $\pi$ $\lambda \eta \psi \imath \varsigma$ ", ifadesinden 'şüpheyi' simgeleyen ve pembe pelerinli yeşil giysisi içinde başı kısmen örtülü olarak resmedilen figür, bakışlarıyla karşıdaki figür grubuna bir şeyler anlatmaya çalışırken, sol eliyle teraziyi veya oturan figürü gösterir biçimde betimlenmiştir. En soldaki kadın figürü diğer ikisinden farklı olarak başı örtülü, pelerinsiz, kollarını da kapatan mavi renkli uzun giysisi içinde, ellerini dua eder pozisyonda birbirine kavuşturmuş şekilde düşünceli bir yüz ifadesiyle resmedilmiştir ve 


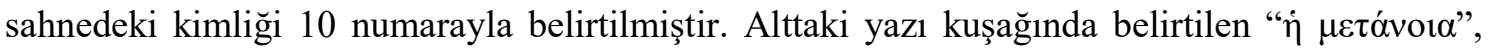
ifadesinden figürün 'pişmanlığı' simgelediği öğrenilmektedir.

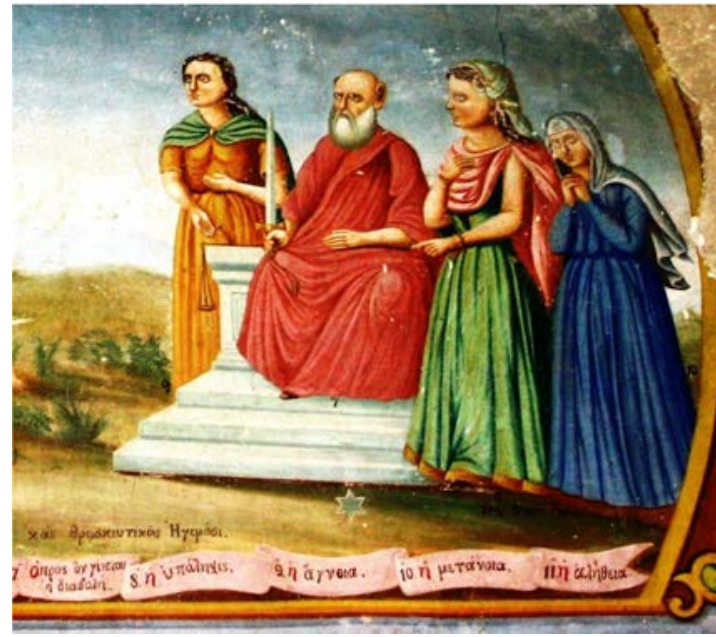

Fig 2. Mustafapaşa (Sinasos), Apelles'e Iftira Atılması (Detay). Canseverler Konağı.

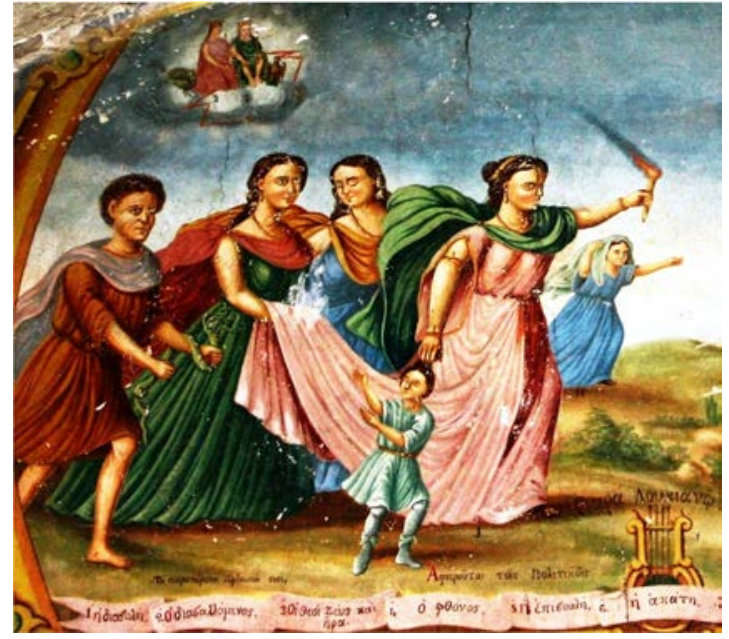

Fig 3. Mustafapaşa (Sinasos), Apelles'e Iftira Atılması (Detay). Canseverler Konağı,

Resmin sol tarafindaki grup daha fazla figürü içerir (Fig 3). Gruba hâkim olan öndeki kadın figürü 1 numarayla gösterilmiş olup, yeşil pelerini, abartılı kıvrımlarla gösterişli ve uzun eteği arkasındaki nedimelerince toplanmış pembe giysisi içinde, diğerlerinden farklı olarak toplanıp topuz yapılmış saçları, bileğinde bilezikleri, kolyesi ve küpeleriyle alımlı bir genç olarak

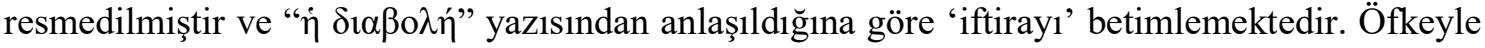
açılmış kocaman gözleriyle karşısındaki gruba bakan kadın sol elinde yanan bir meşale tutmakta, sağ eliyle de 2 numarayla tanımlanmış ve diğerlerinden daha küçük, adeta bir oğlan çocuğu olarak betimlenen figürün saçlarından asılmaktadır. 2 numarayla tanımlanan ve "ó $\delta 1 \alpha \beta \alpha \lambda \lambda o ́ \mu \varepsilon v o \varsigma$ ” yazısından anlaşıldığına göre 'iftiraya uğrayanı' simgeleyen gri giysiler içindeki figür, geriye dönük pozisyonda, ellerini dua eder biçimde yalvarırcasına gökyüzüne açmış olarak resmedilmiştir. Elinde meşale tutan kadın figürünün arkasındaki iki figürden biri 5 numarayla tanımlanmıştır ve " $\dot{\eta} \dot{\varepsilon} \pi \_\beta o v \lambda \eta$ ” ifadesinden 'entrikayı' simgelediği anlaşılmaktadır. Kırmızı pelerinli uzun yeşil elbisesiyle öndeki figürün eteğini toplamış şekilde gösterilmiştir. Yanındaki mavi elbiseli, kahverengi pelerinli kadın ise sağındaki figüre bakar biçimde resmedilmiş olup 6 numarada ifade edilen " $\hat{\jmath} \alpha \dot{\alpha} \alpha \dot{\tau} \eta$ ” yazısından 'hileyi' simgelediği öğrenilmektedir. Figür grubunun en solunda, dizleri üzerine gelen kahverengi giysisi ve mor peleriniyle bir erkek figürü yer alır. 4 numarayla tanımlanan ve "ó $\varphi \theta$ óvo $\varsigma$ " yazısından 'kıskançlı̆̆ı' simgelediği anlaşılan figür, iki eliyle yedi başlı bir yılanı tutar şekilde ve yalın ayaklı olarak betimlenmiştir. Figür grubundan daha geride resmedilen ve 11 numarayla tanımlanan kadın figürü, kollarını açıp koşar biçimde sağdaki gruba doğru hamle yapmış şekilde uzun mavi giysisi ve gri başörtüsüyle gösterilmiştir. Aşağıdaki yazı kuşağına işlenmiş “ $\alpha \hat{\alpha} \eta \hat{\theta} \theta \varepsilon ı \alpha$ ” ifadesine göre figür 'hakikati' simgelemektedir.

Resmin sol üst köşesinde, bulutlar üstünde oturur vaziyette ellerinde asaları, başlarında dört dilimli taçları, yanlarında atribüleri tavuskuşu ve kartalla, pembe ve yeşil giysiler içinde Hellen pantheon'undan Hera ve Zeus betimlenmiştir. Her iki figür de 3 numara ile tanımlanmıştır. Res-

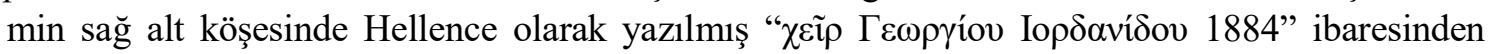
resmin, '1884 yılında Georgios Iordanidis tarafından' yapıldığı ögrenilmektedir. Aynı isim ve tarih, resmi alttan sınırlayan ve rakamların simgelediği kavramları açıklayan yazı bandında, 10 numaralı kavramın hemen altında Latince "Georgi I. Pitore 1884" şeklinde tekrarlanmıştır (Fig 4). 
Resimdeki yazıda Ephesoslu olduğu ifade edilen ve Hellenistik Dönem'in en ünlü ressamlarından biri olan Apelles ile ilgili en detaylı bilgileri Romalı tarihçi ve doğa bilimcisi Plinius'un Historiae Naturalis adlı eserinde bulmak mümkündür. Plinius'a (Bostock \& Riley 1857, 256-263) göre, Koslu olan Apelles, MÖ. 332-329 y1lları arasında düzenlenen 112. Olimpiyatta diğer tüm ressam-

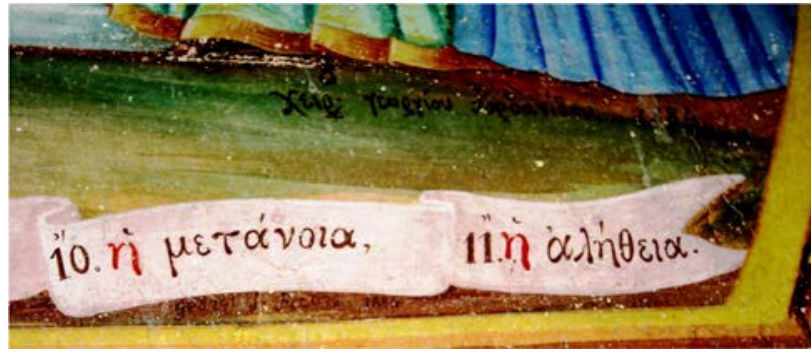

Fig 4. Mustafapaşa (Sinasos), Apelles'e Iftira Atılması (Detay). Canseverler Konağı. lardan daha başarılı olmuş, resim sanatına çağdaşlarından daha fazla katkı yapıp bazı prensipler ortaya koymuştur. Tanrı vergisi bir yeteneğe sahip olduğu belirtilen Apelles'in çağdaşı ressamlardan Protogenes'i takdir ettiği ve hatta bazı noktalarda kendisinden üstün gördüğü, çizim ve resim üzerine hemen her gün egzersizler yaptığı, bitirdiği resimlerini herkesin görebileceği yerde sergileyip, resmin arkasına gizlenerek kamunun resimle ilgili yargısını önemsediği kaydedilir. Büyük İskender'in sık sık Apelles'in atölyesine uğradığı, Apelles dışındaki ressamların resmini yapmasını yasakladığı ve bazı resimlerinde model olarak kullandığı metresi Pankaste'yi ona hediye ettiği de Plinius'un notları arasındadır. Apelles'in hiçbiri günümüze ulaşamamış olan eserlerinden de bahseden Plinius'a göre, resimlerini bitirdiğinde üzerlerine ince bir tabaka halinde sürdügü siyah vernik (cila) figürleri oldukça canlı göstermektedir. Ephesos'taki Artemis Tapınă̆ı'na yaptığı Büyük İskender resminde olduğu gibi bazı resimlerini sadece dört renk kullanarak yaptığı, renklerdeki parlaklık ve tonlamalarla resimlerinde derinlik olduğu belirtilen Apelles'in Mısır'ın halimi Lagos'un oğlu Ptolemaios I Soter ile arasının iyi olmadığı anlatılır. Ancak bu makalede ele alınan resme konu olan iftira olayından Plinius'un eserinde bahsedilmemesi oldukça ilginçtir. E. H. Gombrich (1976, 14-15), Apelles'in çalışmalarıyla ilgili olarak Plinius'un anlatımlarından hareketle, onun resimlerinde kullandığı parlaklığın (veya cilanın) resimde nesneyi öne çıkaracak, resme derinlik kazandıracak bir yöntem olduğunu ileri sürer.

15-16. yüzy1l Rönesans ressamlarının neredeyse hepsinin betimlediği (Cast 1981) ve makalemize konu olan sahnenin detaylı anlatımı ilk kez Samsatlı Lucianus'un (125-200) eserinde görülür. Lucianus, iftira üzerine yazdığ 1 denemede cehaleti, gerçeklerin üzerini örten, hakikati gizleyen ve insanoğlunun yaşadığı bütün sstırapların kaynağı olarak niteler. İftiranın da cehalet kaynaklı bir davranış olduğunu kaydederek, iftira yüzünden babaların çocuklarına, kardeşlerin kardeşlerine, çocukların atalarına, sevenlerin sevdiklerine düşman olabileceğini, iftiraya inanmak yüzünden nice dostlukların parçalandığını ve yeminlerin bozulduğuna dikkat çekerek, bu konunun Apelles'in başından geçmiş bir olayla resmedilmiş olduğunu ileri sürer. Lucianus'a göre, Apelles'e kral Ptolemaios'a karşı Tyros'ta Fenike valisi Theodotas'ın başlattığı ayaklanmaya katıldığı iftirası atılmıştır. Bu iftirayı Apelles'in rakiplerinden olan ve onun kraliyet nezdindeki itibarını ve sanatındaki şöhretini kıskanan Antiphilos adında bir ressam atmıştır. Antiphilos, I. Ptolemaios'a, Apelles'i Phoinike'de Theodotas ile birlikte yemek yerken gördüğünü söyleyerek, Tyros ayaklanmasının ve Pelusium'un düşmesinin Apelles'in girişimiyle olduğunu beyan etmiştir. Ptolemaios söylenenlere araştırıp, soruşturmadan inanmış, Apelles'i nankörlük, işbirlikçilik ve komploculukla suçlamıştır. Apelles'le birlikte suçlananlardan birinin Antiphilos'un, Apelles'e iftira attığını, hiçbir şekilde Apelles'in kendileriyle birlikte olmadığını söylemesiyle Ptolemaios yaptıklarından çok utanıp, Apelles'e 100 talanta (25.86 kg'lık ağırlık ölçüsüdür. Antikitede, 1 talanton yaklaşık olarak 60 mnai, 6.000 gümüş drakhmai ya da 36.000 oboloi'a eşittir) bağışlamış ve Antiphilos'u ona hizmet etmesi için köle vermiştir (FowlerFowler 1949, 1-2). 
Lucianus, iftiranın suçlananı göz ardı eden, tek bir taraftan gelip koşulsuz inanılan bir suçlama olduğunu ifade ederek, iftira suçlamasında iftiracı, iftiraya uğrayan ve iftirayı duyan olmak üzere üç karakter olduğunu belirtir ve bu karakterlerin başına gelmesi muhtemel durumları anlatır. Birincisi, müfterinin iyi bir adam olmadığı kesindir, hiçbir iyi insan arkadaşını incitmez. İyi insanların ünü ve onların merhamete olan inancı arkadaşlarına bahşettikleri faydaya bağlıdır. İkincisi, bu türden bir kişi adalete, kanunlara ve merhamete karşı ve duyarsızdır ve onunla birlikte hareket edenlere beladır. Eşitsizlik ve hilekârlık adaletsizliğin şartlarıdır ki, herkes bunları kabul eder diyerek Apelles'in resmini şöyle anlatır:

“Sağda, neredeyse Midas'ınkine benzer kocaman kulakları olan ve elini yaklaşmakta olan Iftira'ya doğru ileri uzatan bir adam oturur. Bu adamın yakınında iki kadın durur. Kanaatimce bunlar Cehalet ve Kuşku'dur. Diğer tarafta, fazlastyla güzel bir kadın figürü olan ancak, hem hırsl hem de telaş içerisinde ve aynı şekilde gözü dönmüşlük ve hiddet sergileyen Iftira yaklaşmaktadır. Zira sol elinde yanan bir meşale tutmakta, diğer eliyle ise, ellerini gökyüzüne açmış, Tanrıların şahitliğini uman bir delikanlıyı saçlarından sürüklemektedir. Iftiraya solgun ve çirkin, ayrıca keskin baklşl ve uzun süreli hastalıklarla harap olmuş görünen bir adam eşlik etmektedir. Bu kişinin Haset olduğu düşünülebilir. Ayrıca Iftira'y yönlendiren, giydiren ve hazırlayan başka iki kadın ona eşlik eder. Bana göre ve resmin ilerleyişinin ifşa ettiği üzere bu kadınlardan birisi Ihanet, diğeri ise Hilekarlıktır. Arkasından tamamen yas halinde betimlenmiş, siyah giyimli paçavralar içerisinde bir kadın takip etmektedir, sanırım ona Pişmanlık deniyordu. Böylece ağlayarak arkasını dönmüs ve tamamen utançla, yaklaşan Gerçek'e kaş altından bakmaktadır. Apelles kendi başına geleni resme işte böyle döktü"' (Fowler \& Fowler 1949, 2-3).

David Cast (1981, 10), Apelles ve başından geçtiği kabul edilen iftira komplosuyla ilgili olarak, Plinius'un anlatımlarıyla Lucianus'un anlatıları arasında zamandizimsel açıdan yaklaşık 100 yıllık bir fark olmasına rağmen, 17. yüzyıla kadar konunun bu yönüyle hiç tartışılmadığını belirterek, 15-18. yüzyıllar arasında pek çok ressam tarafından betimlenmiş popüler bir konu olduğunu ileri sürer.

Lucianus'un iftira üzerine denemeleri Konstantinopolis'te, VI. yüzyıldan itibaren Süryanice yazılmış bir nüshadan küçük değişikliklerle çevrilerek okunmuştur. Lucianus'un eserinden yapılan çıkarım, saray hayatının tehlikeleri ve sürekli entrika ortamında kalan ahlaklı insanların hayatlarıdır (Cast 1981, 20).

Rönesans ile birlikte antik sanata ve döneme duyulan ilginin bir sonucu olarak, Samsatlı Lucianus'un Iftira Üzerine Diyalog adlı eseri önce Latince'ye sonra pek çok Avrupa dillerine çevrilmiştir. Eseri Batı dünyasında yayımlayan ilk kişi İtalyan bibliyofil Veronalı Guarino Guarini'dir. 1395-1396 ve 1403-1408 yillar1 arasinda Konstantinoplis'te olduğu ve 1410-1413 yılları arasında Floransa'da Hellence öğretmenliği yaptı̆̆ 1 bilinen Guarini'nin, tercümesini 1403-1408 yılları arasinda yazmış olabileceği kabul edilmektedir. Altrocchi (1921, 457-459), 15. yüzy1lda Samsatlı Lucianus'un eserlerinin Guarini'den başka yazarlar tarafindan da çevrildiğini Förster'in yayınından hareketle ileri sürerek bunların;

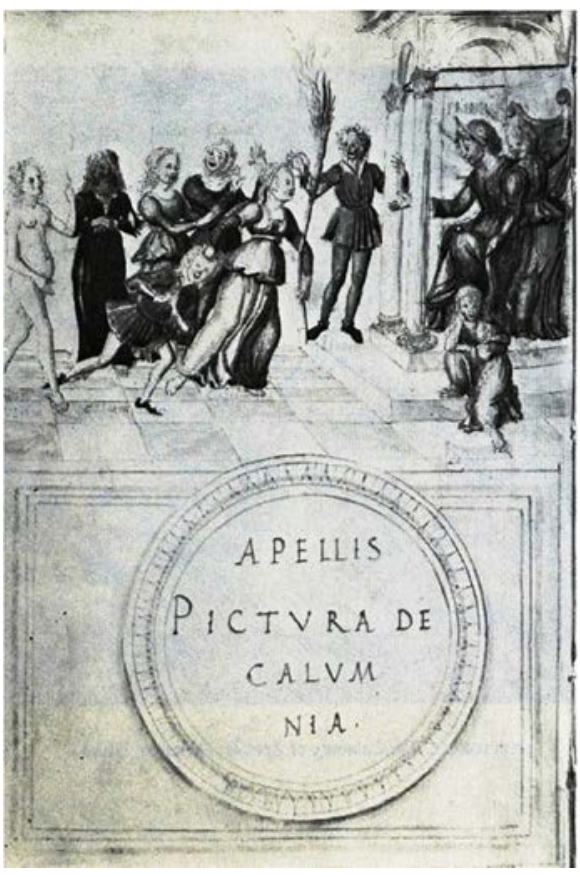

Fig. 5. Bartolommeo della Fonte, The Calumny of Apelles, Berlin, Staatliche Museen. 
Giovanni Aurispa (1372-1460), Lapo Birago da Castiglionchio, Francesco Filelfo (1398-1481), Francesco Accolti, Bartolommeo della Fonte (1445-1513), Poggio Bracciolini (1380-1459), Riniccio da Castiglione ve Bordo olduğunu kaydeder. Adı geçen yazarlar içinde Lucianus'un Iftira Üzerine Diyalog'unu çeviren tek kişi Bartolommeo della Fonte'dir (Altrocchi 1921, 461). Konuyla ilgili en detaylı çalışmayı yapan David Cast eserine 1408-1819 yılları arasında yapılmış 46 tercümeyi ek olarak koymuştur (Cast 1981, 198-231). Lucianus'un metnini Batı dünyasıyla ilk tanıştıran Veronalı Guarino Guarini, çalışmasını hamisi Giovanni Qeurini’ye ithaf etmiştir. Venedik hükümetinde bir yönetici/memur olan Querini'nin iftira ve müfteriyi kolayca fark edebilen, yüksek ahlaklı ve aynı zamanda âlim bir kişilik olduğu belirtilir (Cast 1981, 21). Floransalı âlim Bartolommeo della Fonte, Ferrara dükü Ercole için hazırladığı 1472 tarihli tercüme metninin başına İftira sahnesini betimlediği bir minyatür eklemiştir. Bu etkileyici minyatür (Fig 5), konunun Batı dünyasında yapılmış ilk resmidir (Cast 1981, 42).

Yukarıda adı geçen kişilerin metnin Batı dünyasına ulaşmasında ne kadar katkısı olduysa, konunun yüzyıllar boyu Avrupa resminde tekrar tekrar ele alınıp işlenmesinde de Leon Battista Alberti'nin öncü rolü olmuştur. Floransalı mimar, bilim adamı, dil bilimci ve hümanist Leon Battista Alberti (1404-1472), Lucianus'un İftira Üzerine Diyalog adlı eserinin İtalyancaya çevirisini yapmakla birlikte, 1435 de yazdığ 1 Trattato della Pittura (Resim Üzerine) adlı eserinin üçüncü kitabında ressamlara nasihat verirken Apelles'in İftira resminden de bahseder. Alberti, bir ressamın iyi bir eğitimden geçmiş olmasını, fakat her şeyden önce çok iyi geometri bilmesi gerektiğini, ilaveten şair ve hatiplerle dostluk kurmalarını tavsiye eder. Zira O'na göre şairler ve hatipler resme konu olabilecek edebî metinlerin yaratıcısıdırlar. Bu dostluklar sayesinde kendilerinden önceki devirlerin "menkıbeleri" (historia) hakkında bilgi sahibi olabileceklerini ifade ederek, muhtemelen Guarino Guarini'nin Lucianus tercümesinden aldığı notlarla Apelles'in tablosunun tasvirini yapar ve "ĕger bu menkıbe (historia) sözle anlatıldı̆̆ında bile bu kadar ilgi çekebiliyorsa, usta bir ressamın elinden çıkmış tablo olarak tasvir edildiğinde insana ne kadar zevk verebileceğini tahmin edebiliyor musunuz? " diyerek dönem ressamlarının bu konuya dikkatini çekmiştir (Alberti 2004, 88-89).

Leon Battista Alberti'nin yukarıdaki notlarından sonra konunun tablo niteliğindeki ilk tasviri, Sandro Boticelli tarafindan 1494 yılında yapılmıştır (Fig 6). Boticelli'nin Antonio Segli’ye verdiği bu resmi Medicilerde var olan bir resimden ilhamla yaptığı da söylenir. Zira Segli ailesinin Medicilerle bağlantıları olduğu, Medicilere ait 1492 tarihli bir envanter çalışmasında Fransız tarzında yapılmış bir Musa ve bir Apelles İftirası resmi bulunduğu kaydından hareketle, bahsi geçen resmin Boticelli kadar Bartolommeo della Fonte'ye de kaynak olabileceği ileri sürülür (Cast 1981,49-50). Giorgio Vasari (1898, 239-240), Botticelli'nin resmi Floransalı bir soylu olan Fabio Segli için yaptığını ve Fabio'nun da resmi dostu Antonio Segli'ye hediye ettiğini belirterek, resmin altına da "Bu küçük resim dünyanın hükümdarlarını uyarır | yanlıs yargılamanın zulmünden kaçınsınlar diye. | Apelles bir benzerini Mısır kralına vermişti; o kral | layıktı o hediyeye, hediye de krala" anlamına gelen satırları yazdığını ekler.

Bartolommeo della Fonte'yle birlikte sonraki yıllarda konuyu betimlemiş ressamların çoğunun tablosunda figürler tıpkı Sinasos'taki örnekte olduğu gibi etiketlenmişler ve Lucianus'un anlatısına sadık olarak yönetici veya yargıç, Midas'ınki gibi abartılı büyük kulaklarla betimlenmiştir. Botticelli'nin tablosunda yargıç, bir yönetici prens olarak tasvir edilmiştir. Tablodaki figürlerin düzenlenişi ve Lucianus'un metniyle ilişkisi 1840'larda Giovanni Rosini tarafından yorumlanmıştır. Boticelli'nin resminin muhtemelen kötü yönetimin alegorisi olduğu kabul edilerek, bu bağlamda resmin Piero de Medici'nin kötü yönetimine yönelik bir eleştiri mi olduğu; yoksa Savonarola'nın infazına yol açan şartlara yönelik bir yorum veya Botticelli'nin kendisine 
karş1 yapılmış suçlamalara bir cevap mı olduğu, soruları ortaya atılmıştır (Cast 1981, 31-32).

Lucianus'un Apelles'le ilgili anlatısı Dominique Ingres'in 1863 y1lında günlüğüne düştüğü nota bakılırsa hala çalış1labilecek zengin bir konudur (Cast 1981, 195) ve 15-18. yüzy1l arasında, Bartolommeo della Fonte (1446-1513), Andrea Mantegna (1431-1506), Sandro Botticelli (14451510), Girolamo Mocetto (1470-1531), Raphael (1483-1520), Albrech Dürer (1471-1528), Francisco Salviati (1510-1563) Peter Bruegel (1525-1569), Giorgio Ghisi'nın (1520-1582) ve John Vanderlyn'in (1775-1852) gibi sanatçılar tarafından yağlı boya tablo, kitap resmi veya çizim olarak çalışılmıştır. Resimlerin çoğunda sahnedeki figürlerin simgeledikleri kavramlar başlarının üzerine veya ayaklarının altına yazılmıştır. Resimlerin bazılarında yönetici/kral veya yargıcın bulunduğu sahne Lucianus'un anlatısının aksine resmin sol tarafinda betimlenmiştir. Örneğin Mantegna, Mocetto ve Ghisi'nın resimlerinde iki yanında cehalet ve kuşkuyu simgeleyen kadın figürleriyle yönetici/yargıcın resmin sol tarafında betimlendiği gözlenir. Ghisi'nin resmi dışındaki örneklerde kavramlar figürlerin alt veya üstlerine yazılıdır (Fig 7, 8, 9).

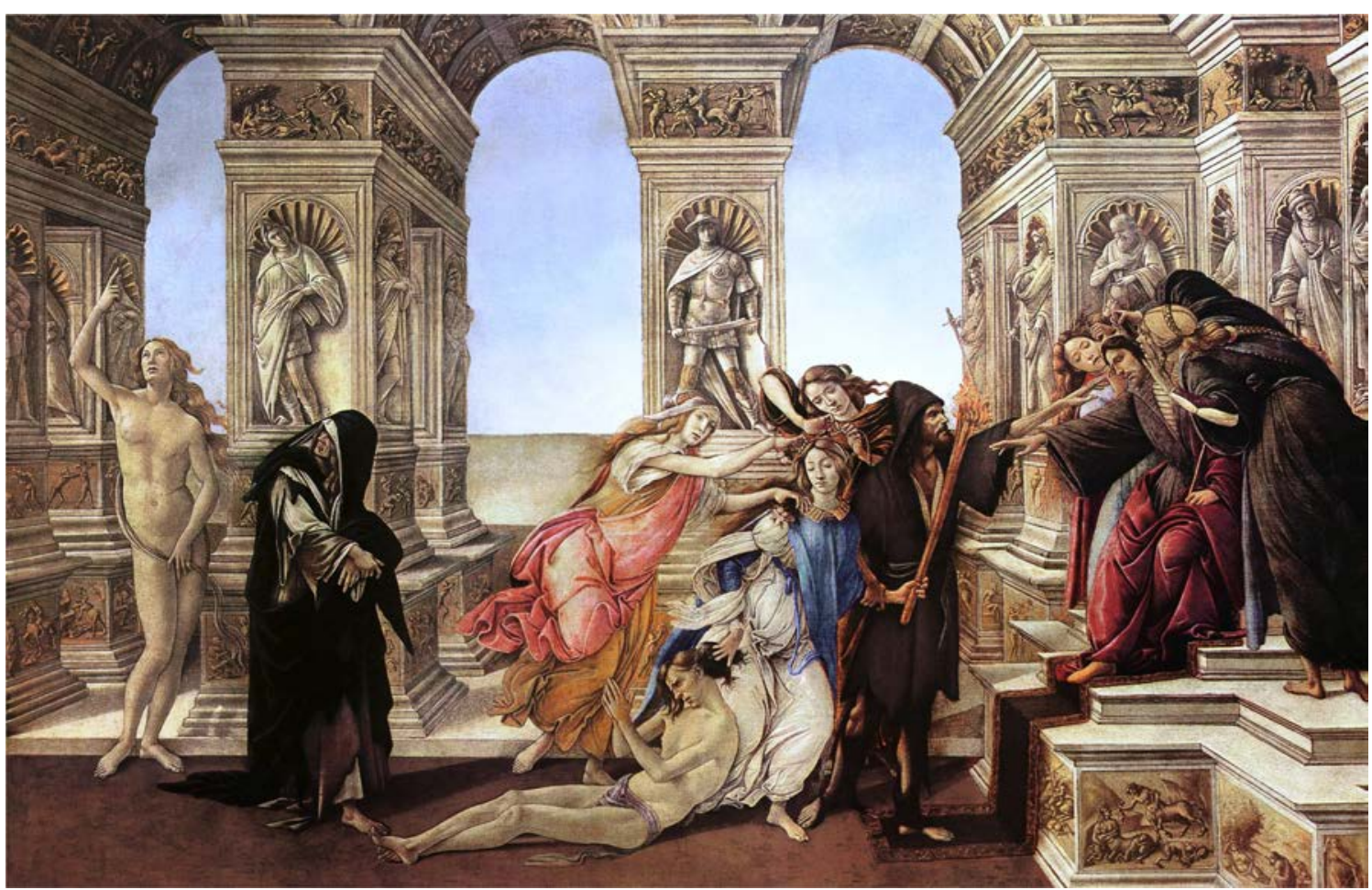

Fig 6. Sandro Botticelli, The Calumny of Apelles, Florence, Uffizi

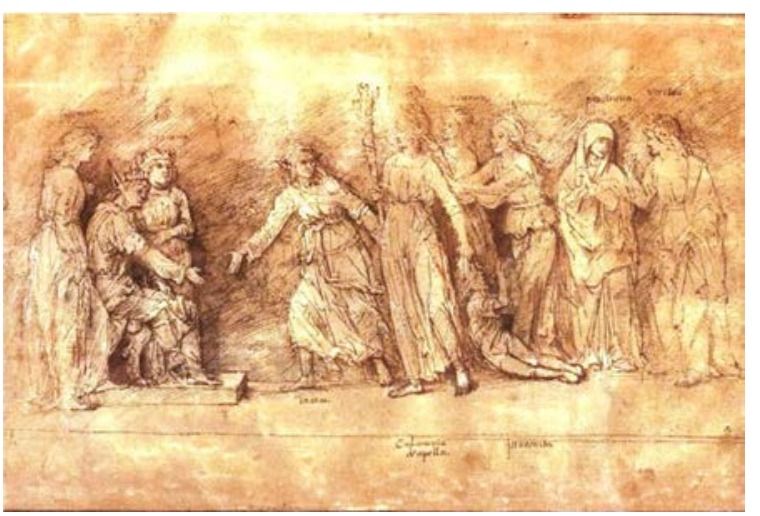

Fig. 7. Andrea Mantegna, The Calumny of Apelles, British Museum. London,

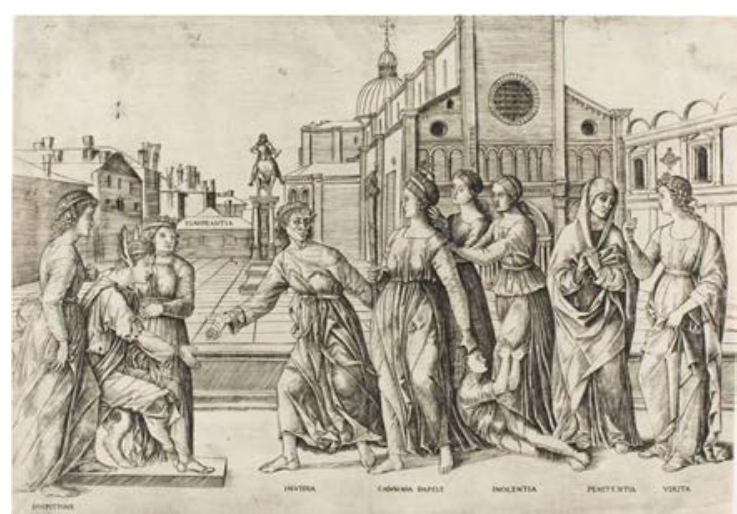

Fig. 8. Girolamo Mocetto, The Calumny of Apelles, British Museum. London 
Bartolommeo della Fonte, Botticelli, Raphael, Bruegel, Dürer, Salviati ve Vanderlyn'in resimlerinde (Fig 10, 11, 12, 13, 14), yönetici/yargıç sahnesi resmin sağında betimlenmiş, della Fonte, Bruegel, Dürer dışındaki sanatçıların eserlerinde figürlerin simgelediği kavramlar yazılmamıştır. Dürer'in resmi dışında tüm eserlerde hakikat çıplak bir kadın figürü olarak betimlenmişken, Dürer'in çiziminde hakikat, elinde güneş motifi tutan bir figür olarak resmedilmiştir ve iftiraya uğrayan figürün ellerini açıp yöneticiye yalvarır şekilde gösterilmesiyle de diğerlerinden farkl11ık gösterir.

Georgios Iordanidis'in resminde, yönetici/yargıç sahnesi resmin sağına işlenerek Lucianus'un anlatımına sadık kalınmış ancak, yönetici/yargıcın iki yanında cehalet ve kuşkuyu simgeleyen iki kadın figürü olması gerekirken, pişmanlığı simgeleyen bir kadın figürü de bu sahneye yerleştirilmiştir. Avrupa'da yapılmış örneklerden farklı olarak hakikat giyinmiş bir kadın olarak betimlenmiş, iftiraya uğrayan figürün yalvardığı tanrı bulutlar üstünde Zeus ve Hera tasviriyle anlatılmaya çalışılmıştır.

\section{Sanatçı}

Başkent dışındaki duvar resimlerinin bölgesel özellikler, kronolojik gelişim ve üslûp birliği göstermediği, örneklerin 18. yüzyılda başlayıp 20. yüzyılda da devam eden modernleşme çabaları içinde yeni zevk ve beğenileri benimsemiş Müslüman veya Hıristisyan yerli sanatçıların eserleri olduğu kabul edilerek, bazı örneklerde başkentten gelmiş/getirilmiş ustaların çalışmış olabileceği ileri sürülür (Arık 1999, 432-433). Ancak İnci Kuyulu'nun $(1998,66)$ İzmir ve çevresindeki örnekler üzerine yaptığı araştırma, resimler içinde kronolojik bir gelişimin varlığını ve belirli bir sanatçı grubunun ortak bir resim dili kullandıklarını ortaya koymuştur. Anadolu'daki duvar resimlerinin çoğunda sanatçı imzasının bulunmamasına karşılık Sinasos'daki duvar resimlerinin neredeyse tamamında sanatçı imzasıyla karşılaşılır. Günümüze ulaşabilmiş

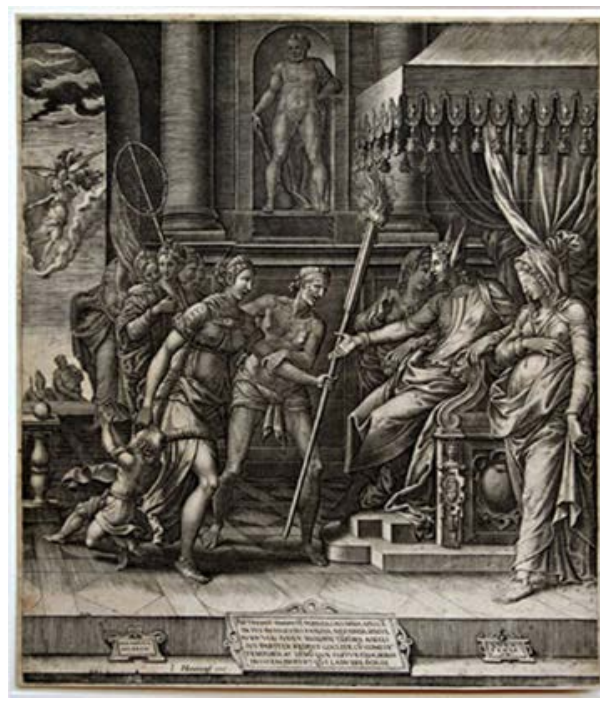

Fig 9. Giorgio Ghisi, The Calumny of Apelles. The Metropolitan Museum of Art. New York örneklerde Kostis Meletyades, L. Aleksiadis ve Georgios Iordanidis'in isimleri okunabilmektedir. Pek çok resimde görülen imza, kasabadan bir kişi olan ve kaynakların anlattı̆̆ına göre, çocukluğunda İstanbul'daki havyarcı akrabalarından birinin yanında çalışırken, gizlice İtalya'ya kaçarak Roma ve Venedik'e gidip orada dört yıl kalan ve klarnet çalmay1, resim yapmayı öğrenip kasabaya dönmüş olan Kostis Meletyades'e aittir. Resim sanatının bütün türlerinde başarılı olduğu belirtilen Meletyades'in sadece ikonalarla uğraşmadığı; bu konunun uzmanının ressam Yorgi olduğu ileri sürülür (Balta 2007, 146-147). Sacit Pekak (2010, 98), Sinasos, Aziz Basileios Kilisesi ve Meletyades üzerine hazırladığı yakın tarihli bir çalışmasında, 2009 yılında Sinasos'a, dedelerinin yaşadığı mekânları görmeye gelen ve Meletyades'in akrabası olduğunu belirten Kiryakos Vlasiadis'ten aldığı bir mektuptan hareketle, ressamın kasabada resimlediği evlerin bir listesini verir. Liste oldukça kabarıktır ve onun resimlerinden pek çoğu günümüze ulaşmıştır. Meletyades'ten başka, kasabadaki evleri süsleyen duvar resimlerinde iki sanatçının daha imzası görülür. Bunlardan biri, tek resmi günümüze ulaşmış olan L. Aleksiadis (Özbek 2005, 36), diğeri ise makalemize konu olan resmi yapan Georgios Iordanidis'tir. Bunların dışında ressam Stef. Aleksiadis'in, kasabanın ihtiyar heyeti üyelerinden ve okul yöneticiliği yapmış Sarandis P. Arhelaos'u yerel giysiler içinde betimlediği belirtilen portre resmi (Balta 
2007, 137) günümüze ulaşamamıştır. Gerek günümüze ulaşabilen örnekler gerekse de kaynakların anlatımları kasabalıların evlerinin duvarlarına aile bireylerinden birini veya başkalarının portrelerini yaptırmaktan hoşlandıklarını göstermektedir. Örneğin, 1950'lerde doğduğu toprakları gezmeye gelen E. Çalıkoğlu, kasabadan Vamvakidislerin evine yerleşen Türk'ün evi koruduğunu ve önceden yapılmış resmi kazıyıp yok etmediğini ve şans eseri olarak baba Vamvakopulos'un resminin hala evin duvarında bulunduğunu ifade etmektedir (Balta 2007, 171).

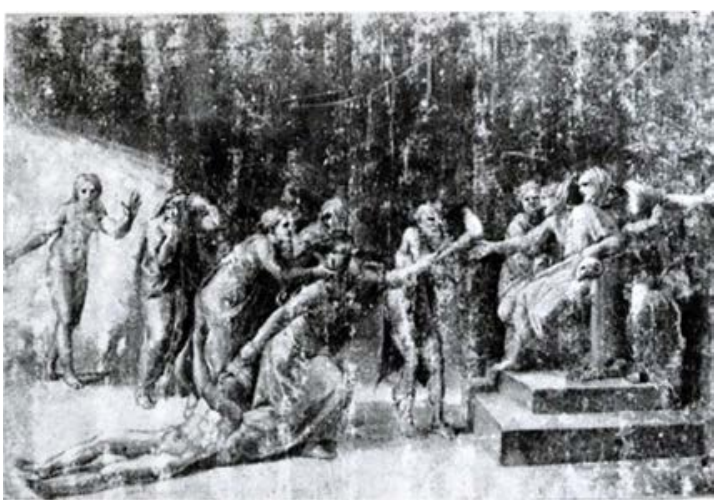

Fig. 10. Raphael, The Calumny of Apelles, Paris, Musée National du Louvre, Cabinet des Dessins.

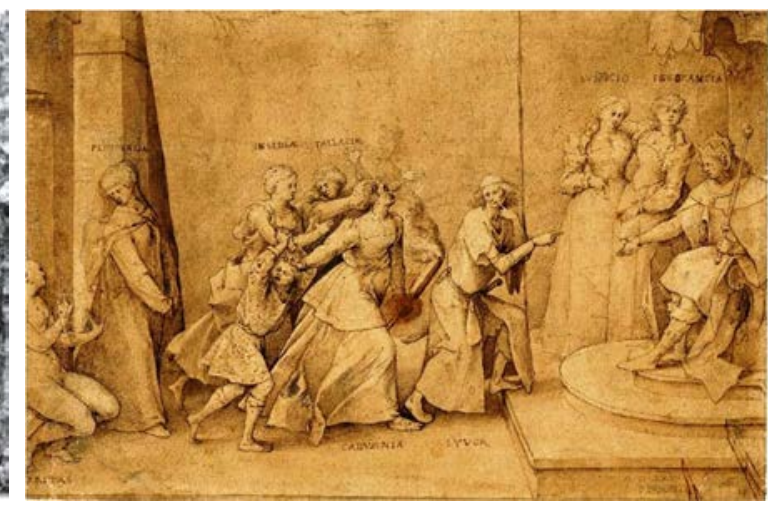

Fig. 11. Pieter Bruegel, The Calumny of Apelles, London, British Museum.

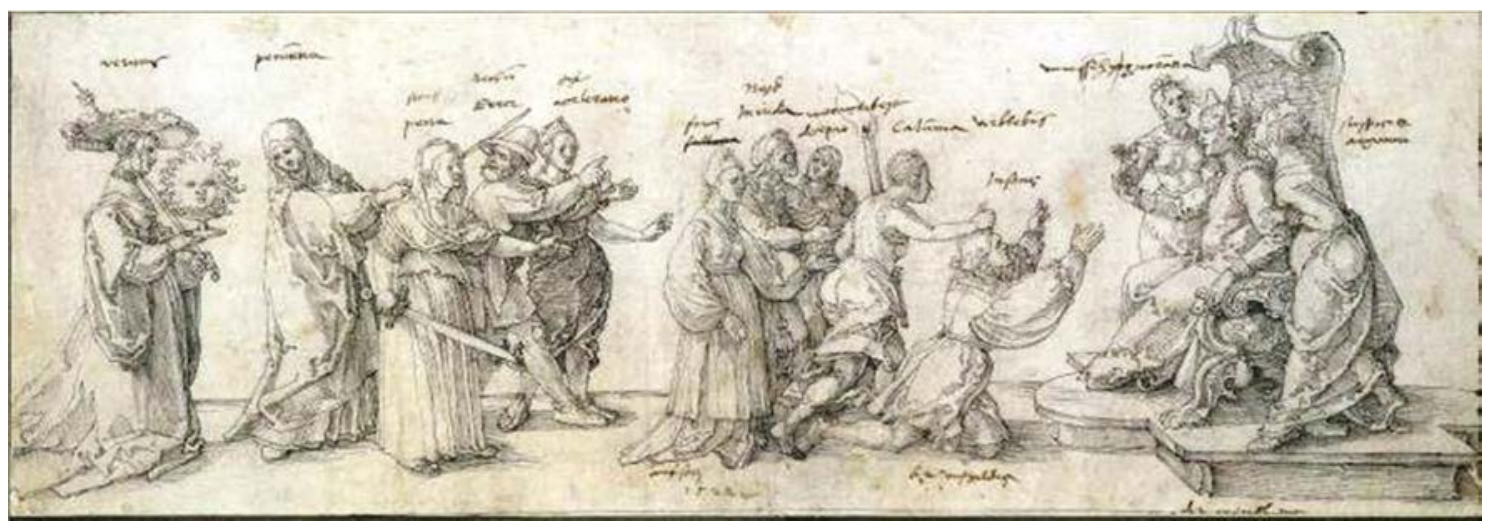

Fig 12. Albrech Dürer, The Calumny of Apelles, Vienna, Albertina.

Georgios Iordanidis'le ilgili olarak kaynaklardaki bilgi bakımından Meletyades kadar şanslı olmadığımızı belirtebiliriz. Acaba ikona ressamı olarak bahsedilen Yorgi ile Georgios aynı kişi midir? Şimdilik buna cevap vermek mümkün olmamakla birlikte, dönem içinde çok sayıda ikona ressamının olabileceği kabul edilmelidir. Tanzimat ve Islahat Fermanlarıyla yapılan düzenlemeler neticesinde İstanbul ve Anadolu'da çok sayıda yeni kilisenin inşa edildiği, mevcutların onarıldığı bilinmektedir. Dolayısıyla bu dönemde kilise duvarlarını bezeyecek resimleri yapacak ustalar veya ikona ressamlarının varlığı normal karşılanacak bir durumdur. Örneğin Kayserili bir ressamın 1887 yılında bölgeden bir yerleşim olan Gelveri'deki Sıvışlı

Kilise'nin naos kubbesindeki azizleri resimlediği bilinmektedir (Pekak 1994, 177-178). Ayrıca, sadece İstanbul'da 19. yüzyılda isimleri tespit edilmiş 28 ikona ressamının 65 kilisede 2270 ikona resimlediği öğrenilmiştir (Şarlak \& Özer 2002, 62). Ortodoks Hıristiyan azınlık için önemli bölgelerden biri olan Kapadokya'da da muhtemelen ikona ressamları vardı. Kaynaklardan edinilen bilgiye göre ikonalar sadece kiliselerde kullanılan birer bezeme unsuru değil; memleketinden uzağa yolculuğa çıkan kimi Rumların yanında götürdüğü ve koruyucu tılsımına inanılan dini bir objeydi. Örneğin Kayserili Rum bir halı tüccarı olan Ionnis Kougioumtzoglou işi dolayısıyla İngiltere'ye giderken yanına resmi kimlik belgeleriyle birlikte, haydutlardan 
korunmak için tabanca ve bıçak alıyordu. Ayrıca yanında Tanrı'nın himayesini sağlamak için de tercihen Aziz Georgios tasvirli küçük bir ikona bulunduruyordu (Augustinos 1992, 96-97). Sinasos'ta Tanzimat Fermanı'nın (1839) ilanından üç yıl sonra Grigori Papalazari Kalfa'ya inşa ettirilen Yukarı Kilisede, giriş kapısının sağındaki duvara yapılmış olan “Klyamet Günü” tasvirinin gerek çizim gerekse renklendirme açısından çok güzel olduğunun belirtilmesi (Balta 2007, 75), yeni kilise inşaatlarının hem yapı sanatçılarına hem de ressam/nakkaşlara yeni iş alanlarının açıldığını anlatan güzel bir örnek olması bakımından dikkat çekicidir.

Georgios Iordanidis'in Meletyades gibi kasabadan birisi mi veya İstanbul ya da başka bir şehirden gelmiş gezgin bir sanatçı mı olduğu hakkında bilgi yoktur. Aynı şekilde resim üzerine bir kursa katılıp katılmadığı veya eğitiminin olup olmadığı soruları da şimdilik cevapsızdır. Ancak kasabada, Ürgüp ve köylerinde başka çalışmaları olduğunu bildiğimiz sanatçının makaleye konu olan resminin altına Hellence adını yazmasından başka, bir de Latince Georgi I. Pitore şeklinde yazması dikkat çekicidir. S. Roides $(1985,155)$, kasabada zengin bir şahıs olarak bilinen Faslaha'nın evindeki duvar resimlerinde bir İtalyan ressamın çalışmış olduğunu belirtirse de, makalemize konu olan sanatçının adı bir İtalyan'dan çok Rum'u çağrıştırmaktadır.

Georgios Iordanidis'in bahsettiğimiz resmi dışında Sinasos ve Ürgüp'teki bazı konut ve kiliselerde de çalışmaları olduğu bilinmektedir. Sinasos'ta günümüzde butik otel olarak kullanılan ve mübadeleden önce Yanni Torosis'in damadı Yarha Vasil için yaptırılan konağın ikinci katındaki 1887 tarihli resim sanatçının imzasını taşımaktadır. Resim bahçe ya da orman içinde salıncakta sallanan genç bir erkek ve kadını betimlemektedir. Resmin üst bölümünde de Rumca bahar anlamına gelen "EAP" yazısı dikkati çeker (Fig 15). Bu resmin muhtemelen Georgios Iordanidis tarafından yapılmış ve tahrip olmuş bir kopyası da Sinasos'un $6 \mathrm{~km}$ yakınındaki Ürgüp'te Mahmut Altan Evinde yer almaktadır. Resim, 19. yüzyıl Fransız ressamlarından Pierre Auguste Cot'un (1837-1883) 1873 yılında yaptığı Springtime adlı tablosunun (Rubin 1979, 191193) (Fig 16) bir kopyasıdır. Pierre Auguste Cot'un gravür ve duvar halılarında da kopyaları yapılan bu tablosunun bir örneğinin de 1930'lu yıllarda Cumhurbaşkanlığı Köşkü koleksiyonuna (Şerifoğlu 2014, 9) dahil edildiği bilinmektedir.

Üzerinde imzası olmamakla birlikte, kasabada Mustafa Savaş Evinde yer alan, 1885 yılında yapıldığg düşünülen ve "Yaşam Merdiveni" biçiminde adlandırılabilecek olan resmin de (Fig 17) üslûp ve konu itibariyle Georgios Iordanidis tarafından yapılmış olabileceği kabul edilebilir. Anadolu duvar resimleri içinde örneğini görmediğimiz bu çalışmanın da Ortaçağdan 20.yüzyıl başına kadar Avrupa resminde özellikle de kitap resimlerinde örneklerini görmek mümkündür (Burrow 1986). Örneğin 20. yüzyılın başında Alman yayıncı ve matbaacı Eduard Gustav May'ın (British Museum, web) Frankfurt'ta yayınladığı bir renkli litografta bir erkeğin ömrü anlatılırken Sinasos'taki gibi resmin merkezine Cennetten Kovulma sahnesi işlenmiştir (Fig 18).

Sinasos'daki Hagios Vasilios Kilisesi kuzey nef tavanında dairesel bir çerçeve içine betimlenen Pantakrator İsa tasvirinde (Fig 19), çerçevenin kenarında sanatçının adı ve 1915 tarihi okunabilmektedir (Pekak 2010, 90). Sanatçının Ürgüp’te Hıdırellez Kilisesi olarak bilinen ancak içindeki tasvirden hareketle Hagios Georgios Kilisesi olarak ta tanımlanabilecek olan 19.yüzyıl kilisesindeki (Pekak 2014, 199) Isaias ve Jeremias peygamberlerle havari Petrus fresklerini 1899 yılında yaptı̆̆ imzasından anlaşılmaktadır (Fig 20-21). Ayrıca sanatçının bir çalışmasının da Mustafapaşa yakınındaki Cemil Köyü'nde bulunan ve 1838 yılında inşa edildiği belirtilen Kutsal Haç Kilisesi'nde (Pekak 1998, 22-23) bulunduğu tespit edilmiştir. Kilisenin güney duvarı üzerinde bulunan ancak aşırı tahribattan dolayı konusunu anlayamadığımız bir freskonun 1909 yılında Georgios Iordanides tarafından yapıldığı resmin altındaki kitabede kaydedilmiştir (Fig 22-23). 


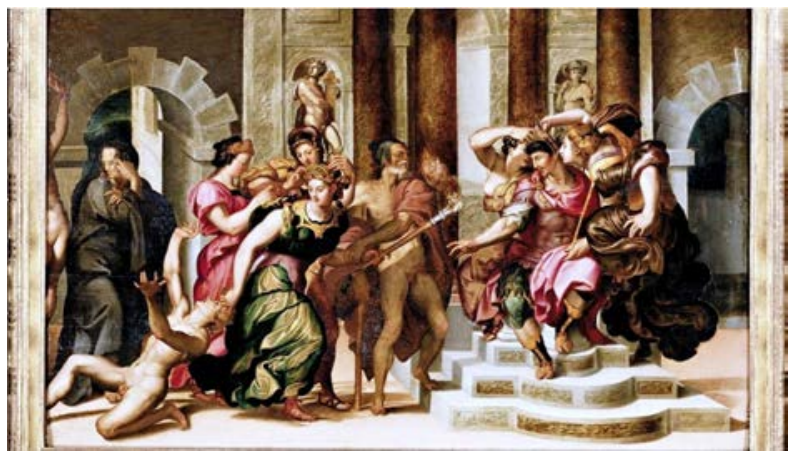

Fig. 13. Francesco Salviati, The Calumny of Apelles, Sotheby's New York.

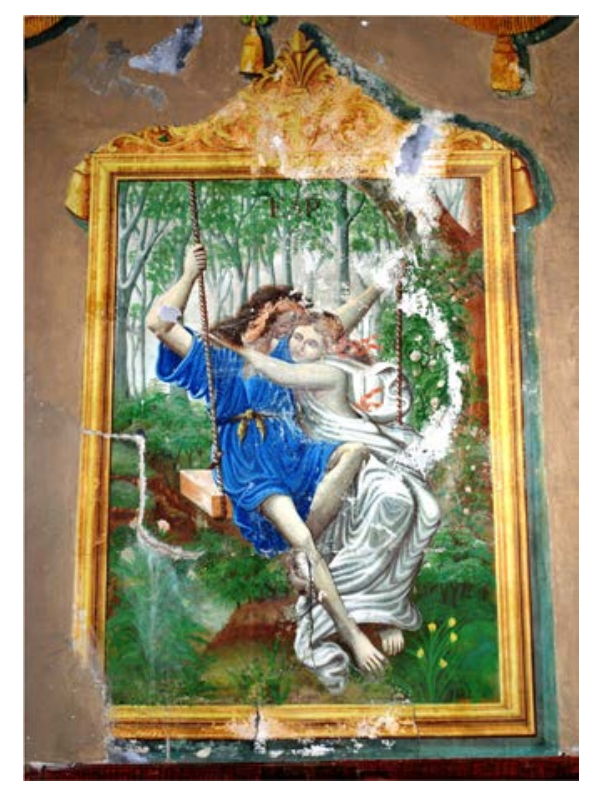

Fig 15. Mustafapaşa (Sinasos), Temel Öztürk Evi, Bahar resmi.

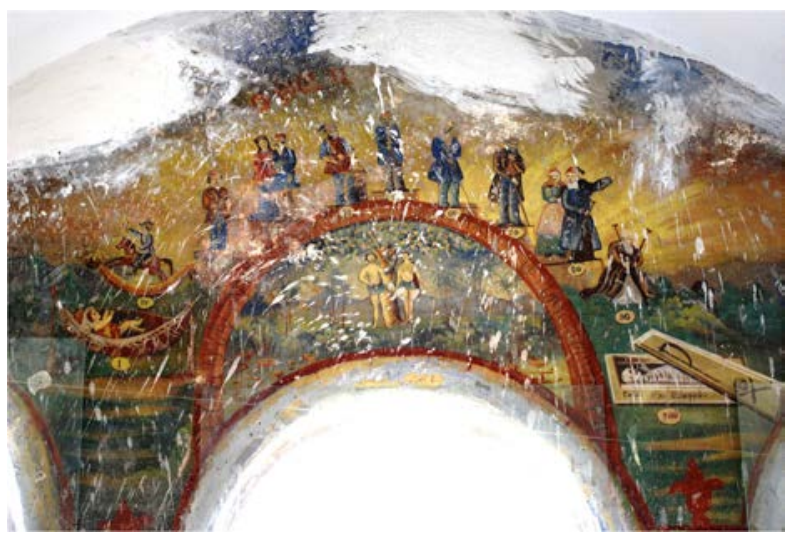

Fig 17. Mustafapaşa (Sinasos), Yaşam Merdiveni Resmi. Mustafa Savaş Evi. (Foto:Y.Özbek)

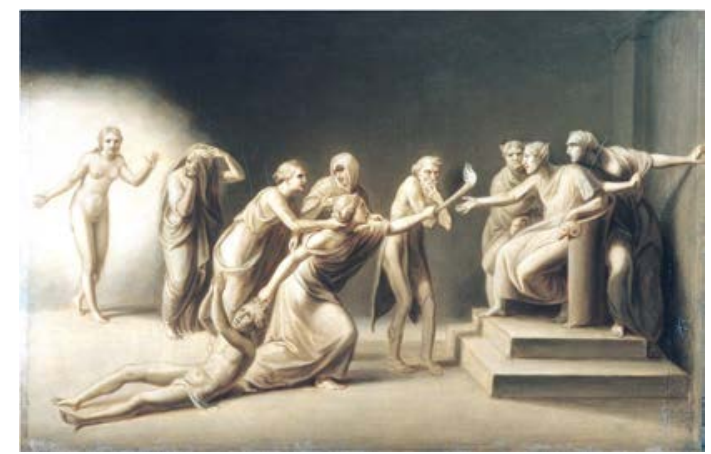

Fig 14. John Vanderlyn, The Calumny of Apelles, New York, The Metropolitan Museum of Art.

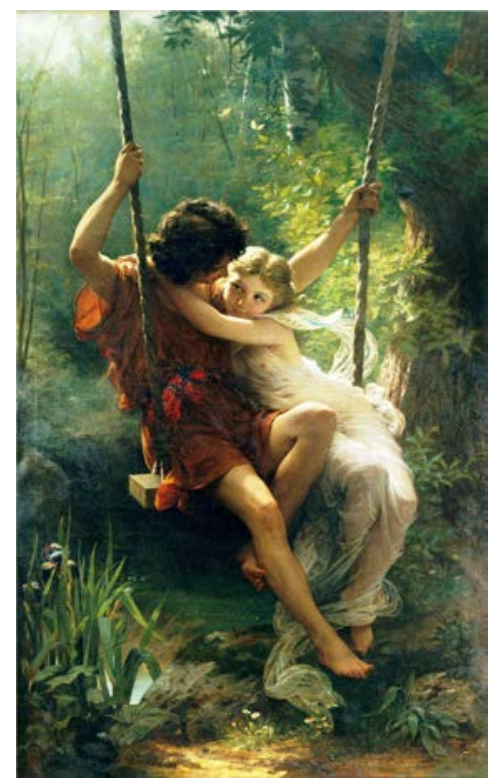

Fig 16. Pierre Auguste Cot, The Springtime, New York, The Metropolitan Museum of Art.

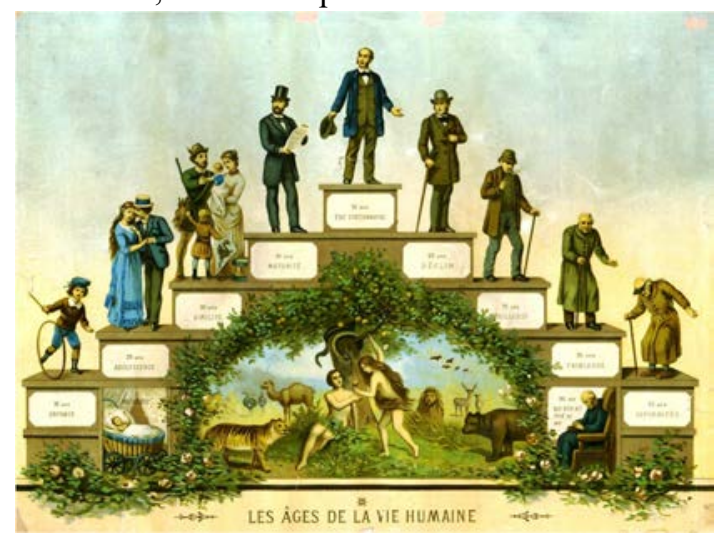

Fig 18. Eduard Gustav May, The Stairway of Life of Human.(https://kykolnik.livejournal.com/479369.html08.03.2015) 


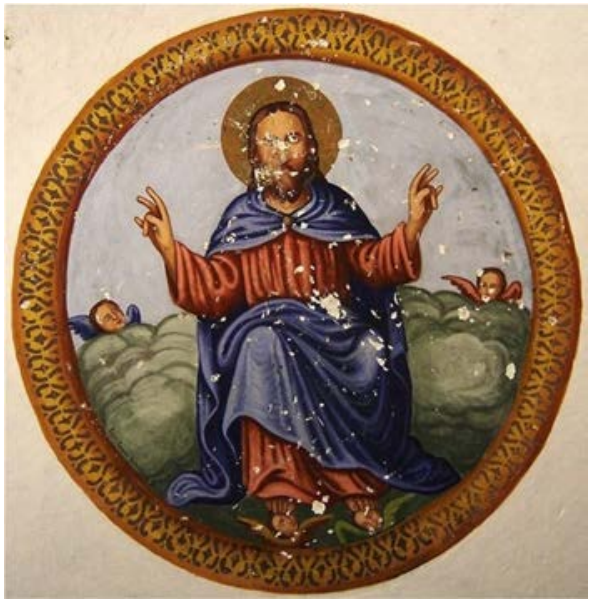

Fig 19. Mustafapaşa (Sinasos), Pentakrator İsa Tasviri. Hagios Vasilios Kilisesi.

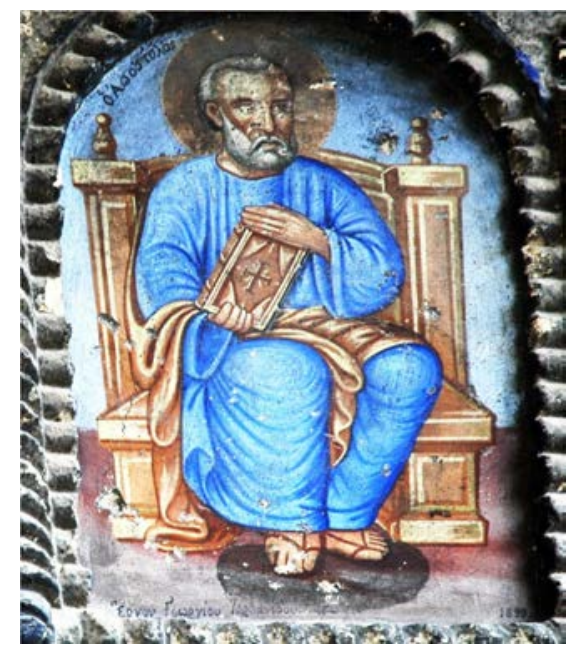

Fig 21. Ürgüp, Havari Petrus. Hidırellez (Hagios Georgios) Kilisesi. (Foto: Y. Özbek)

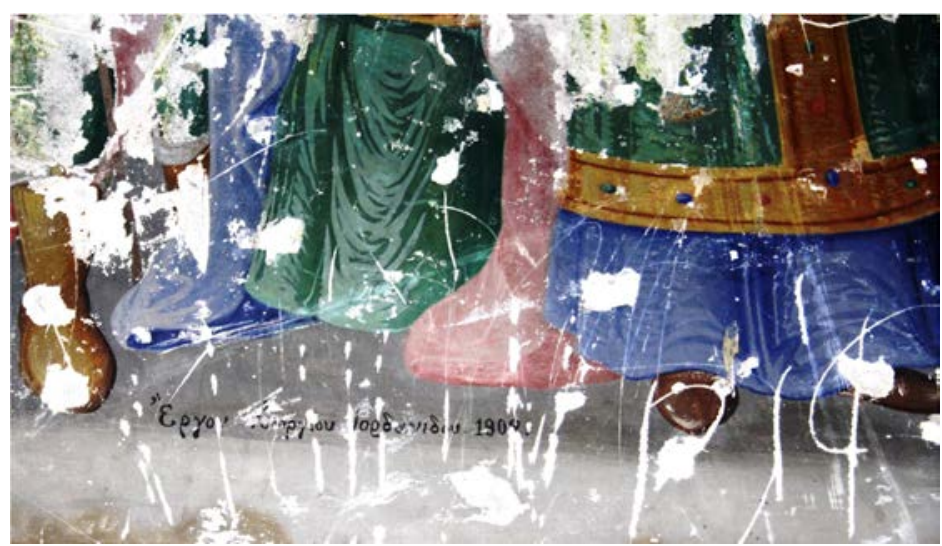

Fig 23. Ürgüp, Cemil Köyü Kutsal Haç Kilisesi, Ressam Geogios Iordanidis'in İmzası 


\section{Değerlendirme}

Osmanlı dönemi Anadolu duvar resimlerinde antik dönem harabelerine benzer tasvirler olmakla birlikte, bir antik dönem kaynağından seçilmiş konunun ele alındığı çalışmayla bu güne kadar karşılaşılmamıştır. Kapadokya ve çevresindeki merkezlerde de örneğine rastlamadığımız bu resmin, içinde yer aldığı Sinasos kasabasının 19. yüzyılın ikinci yarısında geçirdiği sosyoekonomik ve kültürel değişim bağlamında değerlendirilmesi gerekir.

Günümüzdeki adı Mustafapaşa olan Sinasos, Kapadokya'daki önemli merkezlerden Ürgüp'ün 6 km yakınındadır. Kapadokya, 19. yüzyılda nüfusu içinde küçümsenmeyecek sayıda gayrimüslim azınlık barındıran bir bölgedir. Gayrimüslim azınlık içinde Ermenilerle birlikte bölge sakini olan Ortodoks Rumların önemli bir bölümünün Rumca bilmeyip Türkçe konuştukları, çocuklarına Murat, Demir, Yağmur gibi Türk ve Müslüman isimlerini koydukları, kilise ve okul gibi kamu yapılarında Karamanlıca olarak tanımlanan Hellen harfleriyle Türkçe kitabeler kullandıkları ve yine Hellence - Türkçe kitap ve gazeteler yayınladıkları bilinmektedir. Bölge içinde özellikle Kayseri, Niğde ve Nevşehir'de, bahsedilen kitabe ve yayınları görmek mümkündür. Ancak makaleye konu olan resmin bulunduğu Sinasos kasabası, 19. yüzyıl nüfus kayıtlarından öğrenildiğine göre sakinlerinin 3/4'ü Rumca konuşan Ortodokslardır (Dawkins 1910, 117). Kasabanın Ortodoks Rumları, Türkiye Cumhuriyeti ile Yunanistan hükümeti arasında imzalanan 1924 tarihli Nüfus Mübadelesi çerçevesinde Yunanistan'a göçmüştür. Rumlardan kalan ve çoğu 19. yüzyılın ikinci yarısında kesme taş malzemeyle iki katlı olarak inşa edilmiş, konsollu çıkmaları, kemerli açıklıklarla sokağa açılan balkonları ve duvarları resimli gösterişli konakları (Saner \& Yıldırım 2006, 165-179) ve kiliseleri bugün de görebilmek mümkündür.

Kasaba üzerine yapılmış kimi çalışmalar ve mübadeleyle Yunanistan'a göçenlerin anıları ve 19. yüzyıl sonu 20. yüzyıl başında çekilmiş fotoğraflardan hareketle Evangelia Balta tarafindan hazırlanmış kitapta $(2007,62)$ belirtildiğine göre, Müslümanlar da dâhil olmak üzere çoğunlukla Rumlar, kısa süreli çalışmak üzere Niğde, Mersin gibi yakın şehirlere, uzun süreli, iş kurup ve ticaretle uğraşmak için İstanbul'a gitmektedirler. İşyerleri İstanbul'da Galata semtinde bulunan Sinasoslu Rumların havyar ve boya ticaretiyle uğraştıkları ve hatta havyarcılar loncasını ele geçirdikleri bilinir.

Kasabada 1820 yılında Rumlar için bir okul inşa edilmiş, 1840 yılında da Serafim Tandırcı, Hacı Polikarpos, Serafim Rizos, Hacı Tahanasis Teperoğlu, Hristos Fengarinas, Vasilis Maraşoğlu gibi havyarcı ve hayırseverler Erkekler Okulunu yaptırmışlardır. Okulda antik Yunancayla birlikte çocuklara Kathaverusa diye tabir edilen ve o dönem aydınlarının ve kilisenin kullandığ Yunanca öğretilmeye çalışılmaktadır. Ayrıca öğrendikleri Türkçe ve Fransızca'nın İstanbul'daki işlerinde çok yararlı olduğu belirtilerek, Hellence'yi öğrenenlerin neredeyse bir nefeste Homeros'tan dizeler okuyabildiği ifade edilmektedir. Din dersinde Eski Ahit'ten parçalar okunduğu, antik kilise tarihiyle birlikte Pandelis adlı öğretmenin Ksenophon'un Hellence yazılmış “Kyros'un Eğitimi” isimli kitabını okuttuğu kaydedilmektedir (Balta 2007, 101-103). Okulun 10 dershanesi, ayin ve tiyatro için kullanılabilen büyük bir salonu ve 1500 cilt kitabı içeren bir kütüphanesinin olduğu ileri sürülerek, 1900 yılında 250 öğrencinin lisan, matematik, din, tarih, güzel yazı, resim ve müzik dersleri alarak öğrenim gördükleri belirtilir (Stamatopoulos 1985, 44-46). Kasabada 1872 yılında kızlar için de bir okul inşa edilmiş ve öğretmen olarak Atina Arsakeio Lisesi'nden mezun Eleni Haralambus atanmıştır. Okula sonradan gelen Atinalı öğretmenlerin kasabada uzun süreli olarak kalmamaları üzerine, kasaba ihtiyar heyeti burs vererek, kendi kızlarından bazılarını İstanbul veya Atina'da okutup kasabadaki okullarında öğretmen olarak çalıştırmayı amaçlamışlardır (Balta 2007, 114). Kasabanın merkezinde, Mesohori olarak adlandırılan bölgeye 19. yüzyılda İstanbul'da havyarcılık yapan Sinasoslu Hristo Fengarinas'ın 
bir han yaptırdığı ve gelirini kasabanın okullarına bağışladığı bilinmektedir. Yine kasaba merkezinde, altında yedi dükkan bulunan ve geniş bir salon şeklinde tasarlanan ve Müslümanların ziyaret etmediği belirtilen Gazino kahvesi yer almaktaydı (Balta 2007, 57). Hem han hem de Gazino kahvesi günümüze ulaşamamıştır. Gazino kahvesine İzmir, İstanbul ve Atina'dan kimi gazete ve derginin geldiği ileri sürülür (Stamatopoulos 1985, 52). Görüldüğü üzere Sinasosluların 19. yüzyılın ikinci yarısından sonra İstanbul ve Avrupa ile ticaret ve çalışma hayatına bağlı ilişkileri söz konusudur.

Apelles'e İftira konusu 15. yüzyıldan 19. yüzyıla kadar pek çok İtalyan ve Avrupalı ressamlarca resmedilmiştir. Resmi yapan Georgios Iordanidis kasabalı meslektaşı Meletyades gibi İtalya'ya gidip, orada resmin bir örneğini görmüş olabileceği gibi, 19. yüzyılda yaşanan gelişmeler içinde, kasabadaki okulda yer alan antik kaynaklarından da öğrenip yapmış olabilir. 18771878 öğretim yılında Nevşehir'deki Rum mekteplerinde okutulan dersler arasında ikhnographia (mimarî çizim) dersinin olması (Benlisoy \& Benlisoy 2000, 31), konu seçimlerinde antik literatüre başvurulmuş olabileceğini göstermektedir. Ancak kasabadaki okulun kütüphanesinde sayısı 1500 cilt olarak bildirilen kitapların ne kadarının antikçağ kaynağı olduğu veya içlerinde Samsatlı Lucianus'un eserlerinin olup olmadığı hakkında bilgimiz yoktur.

Öte yandan konusunu antik kaynaklarından alan benzer resimlerin kasabadaki diğer evlerde bulunmaması, konunun ev sahibi tarafından belirlenmiş olabileceğini de gösterir. Ev sahibinin İstanbul'da havyar ticaretiyle uğraştığı bilinmektedir. 19. yüzyılın ikinci yarısında İstanbul'a taşradan çalışmaya gelmiş Rumların çoğunun yaptığı gibi Sinasoslu ve Nevşehirli Rumların da memleketlerine okul yaptırmak amacıyla Beyoğlu'ndaki kimi tiyatrolarda temsiller düzenledikleri, dernekleri aracılığıyla okul inşası için bağışlar topladıkları bilinmektedir (Benlisoy \& Benlisoy 2000, 24-43). Ev sahibinin resmin konusunu bahsedilen temsiller veya dernek çalışmaları esnasında öğrenmiş olması da muhtemeldir. Mübadeleyle Yunanistan'a gönderilen kasabal1larla yapılmış sözlü tarih çalışmalarından derlenmiş kitapta, ne evin sahibi olan Faslaha'nın ne de kasabalılardan birinin başından geçmiş iftira olaylarının yaşandığına dair kayıtlar vardır. Resmin yapıldığı yıllarda sultan olan II. Abdülhamid zamanında güçlü bir hafiye teşkilatı ve jurnallerin varlığı bilinirse de (Beyhan 1999, 65-83) resmi yaptıran ev sahibinin bir kovuşturmaya uğradığına dair bilgi ve belge yoktur. Anlaşılan Ingres'in bahsettiği gibi Samsatlı Lucianus'un anlattığı öykü hala resmedilecek ilginç bir konu olarak kabul edilmiştir.

Pierre Auguste Cot'un resminin kopyalanması da ilginç örneklerdendir. 1873'de yapılan resmi Iordanidis'in görüp görmediği bilinmemekle birlikte, 19. yüzyılın sonlarında kimi Fransız ressamlarının tablolarının kartpostalları hazırlanarak Batı Anadolu'daki ve hatta bazı İran şehirlerindeki halı atölyelerinde duvar halısı olarak dokutturuldukları ileri sürülür. Hatta Donald Quataert (1993, 143), 20. yüzyılın başlarında Kayseri'de dokunmuş bir ipek halıda kıvrıla kıvrila akan Seine Nehri ve Eifel Kulesi’yle Paris şehrinin betimlenmiş olduğunu kaydeder. Sinasos'un Kayseri'ye yakınlığı ve 19. yüzyıl sonunda kasabada bir ipek böceği yetiştirme ünitesinin kurulmuş olduğu (Balta 2007, 57) dikkate alınırsa; Georgios Iordanidis'in bu resmi, bölgedeki ipek halı üreticilerinden birinde var olabilecek kartpostaldan çalışabileceği akla yakın gelir. Başka bir ihtimal de sanatçının kendinde bu resimlerle ilgili bir tür repertuvar oluşturacak şekilde kartpostallardan oluşmuş bir albüm olabileceğidir. Stefan Weber (2002, 160-170), 20. yüzyılın başlarında Şam'da kartpostallardan veya fotoğraflardan duvar resimleri, özellikle kent tasvirleri yapan İtalyan sanatçıların varlığından bahseder. Yaşam merdiveni olarak tanımlanabilecek resim de muhtemelen bir kartpostal veya kitap resminden çalışılmış olmalıdır.

Duvar resimlerinin taşraya yayılmasında idari ve ticari burjuvazinin beğeni ve başkente öykünmesi etkili olmuştur. Batılı bir hayat tarzını benimsemeye başlayan, konut mobilyalarını ve 
bezemelerini Batı zevklerine göre düzenleyen ve çoğunluğu Müslüman olan idarecilerden bazılarının tereke veya muhallefat kayıtlarından Fransız kitapları, haritalar, gözlükler, duvar ve kol saatleri, Fransız tepsileri gibi ithal mallara sahip oldukları anlaşılmaktadır (Göcek 1996, 99100). Gerek kitap ve kartpostalların ve gerekse taşınabilen tepsilerin içermiş olabilecekleri resimlerin de (Okçuoğlu 2013, 211-227) duvar resimlerine kaynak olabileceği gözden uzak tutulmamalıdir.

Georgios Iordanidis'in Sinasos'ta imzasının görüldüğü konak ve kiliselerdeki resimler içinde erken ve geç tarihli örnekler arasında 31 yıllık bir zaman söz konusudur. Ressamın bu süre içinde hep kasabada mı olduğu, Ürgüp ve Cemil Köyü dışında başka hangi şehir ve kasabalarda konak veya kiliseleri resimlediği hakkında maalesef bilgimiz yoktur. İsmine bak1lırsa bir Rum olabileceği kabul edilebilir. Ancak Apelles'e İftira resminin altına Hellence attığı imza dışında ayrıca adının yanına ressam olduğunu belirten İtalyanca Pitore ibaresini yazması, Roides'in bahsedilen evde bir İtalyan sanatçının çalıştığı iddiasını destekleyecek bir tavır olarak yorumlanabilir. Daha fazla belge ve bilgiye ihtiyaç duyulmakla birlikte Iordanidis'in yaptığ bilinen "Bahar" resmi ile konu ve üslup olarak ona mâl ettiğimiz "Yaşam Merdiveni" adlı çalışmalar sanatçının Avrupa'daki çalışmalardan kesinlikle haberdar olduğunu göstermektedir.

Sonuç olarak; Kapadokya'nın Kayseri, Nevşehir, Ürgüp ve Avanos gibi diğer merkezlerindeki örneklerle karşılaştırıldığında bu resimler, Sinasos'un 19. yüzyılın ikinci yarısında yaşadığı ekonomik zenginleşmeyi ve Yunanca öğretimi temel hedef edinmiş okullarla tezahür etmiş milliyetçilikle beslenen entelektüel bir hayatı ve başkent İstanbul kadar Avrupa'yla girdiği kültürel ilişkileri yansitan görsel metinler olarak kabul edilebilir. 


\section{KAYNAKÇA}

Alberti L. B. (2004). On Painting. New York 2004.

Altrocchi R. (1921). "The Calumny of Apelles in the Literature of the Quattrocento". Publication of the Modern Language Association of America 36/3 (1921) 454-491.

Arık R. (1988). Batılılaşma Dönemi Anadolu Tasvir Sanatı. Ankara 1988.

Arık R. (1999). “Osmanlı Sanatında Duvar Resimleri”. Osmanlı 11 (1999) 423-436.

Arslan H. (2014). "Boğaziçi’nde 18. Yüzyıldan Kalma Bir İstanbul Evinin Durumu Hakkında Sanat Tarihi Bağlamında Yeni Değerlendirmeler". METU JFA 31/1 (2014) 97-117.

Atasoy N. (1976). "I. Sultan Mahmud Devrinden Bir Abide Ev". Sanat Tarihi Ylllı̆̆ $l$ VI (1976) 23-43.

Augustinos G. (1992). The Greeks of Asia Minor. Confession, Community and Ethnicity in the Nineteenth Century. London 1992.

Balta E. (Ed.) (2007). Sinasos. Mübadeleden Önce Bir Kapadokya Kasabası. İstanbul 2007.

Benlisoy F. \& Benlisoy S. (2000). “19. Yüzyılda Karamanlılar ve Eğitim Nevşehir Mektepleri”. Toplumsal Tarih 13/74 (2000) 24-33.

Beyhan M. A. (1999). "II. Abdülhamid Döneminde Hafiyye Teşkilatı ve Jurnaller”. İlmi Araşstrmalar 8 (1999) 65-83.

Bostock J. \& Riley H. T. (1857). The Natural History of Pliny (6). London 1857.

British Museum Web, www.britismuseum.org/research/search, Erişim Tarihi: 08.03.2015.

Burrow A. J. (1986). The Ages of Man. Oxford 1986.

Cast D. (1981). The Calumny of Apelles. A Study in the Humanist Tradition. New York 1981.

Dawkins R. M. (1910). "Modern Greek in Asia Minor". The Journal of Hellenic Studies 30 (1910) 109-132.

Fowler H. W. \& Fowler F. G. (1949). Lucian of Samosata: The Works of Lucian of Samosata. Oxford 1949.

Gombrich E. H. (1976). The Heritage of Apelles. Studies in the Art of the Renaissance III. Oxford 1976.

Göcek F. M. (1996). Rise of the Bourgeoisie, Demise of Empire. Ottoman Westernization and Social Change. Oxford 1996.

Kuyulu İ. (1998). "İzmir ve Çevresindeki Bir Grup Duvar Resminin İncelenmesi”. Haz. N. Ülker. II.Uluslararası İzmir Sетровуити (1998) 57-78. İzmir.

Okçuoğlu T. (2013). "Late Ottoman Painted Trays: Figuring the Transition to Modernity". Eds. F. Nessi \& M. Hatzaki, Rituals of Hospitality Ornamented Trays of the $19^{\text {th }}$ Century in Greece and Turkey (2013) 211-227. Athens.

Özbek Y. (2005). Mustafapaşa (Sinasos) Evlerinde Duvar Resimleri. Kayseri 2005.

Özbek Y. (2011). "Kayseri Evlerinde Duvar Resimleri”. Eds. Z. Y. Yaman \& S. Bağc1, Tradition, Identity, Synthesis: Cultural Crossing and Art (2011) 209-219. Ankara.

Özbek Y. (2014). "Kapadokya'da Osmanlı Dönemi Duvar Resimlerinde Kent Tasvirleri”. MJH IV/1 (2014) 215-230.

Pekak S. (2014). “Ürgüp Kiliseleri”. Hacettepe Üniversitesi Edebiyat Fakültesi Dergisi 31/2 (2014)173-203.

Pekak S. (1994). "Güzelyurt'ta (Gelveri) Bulunan Bizans/Post Bizans Dönemi Kiliseleri 2". Hacettepe Üniversitesi Edebiyat Fakültesi Dergisi 11/1-2 (1994) 177-216.

Pekak S. (1998). “Kapadokya'da Post Bizans Dönemi Dini Mimarisi 1: Nevşehir ve Çevresi”. AST XV/1 (1998) 1-43.

Pekak S. (2010). "Kasaba, Kilise, Ressam”. Arkeoloji ve Sanat 133 (2010) 77-100.

Quataert D. (1993). Ottoman Manufacturing in the Age of the Industrial Revolution. New York 1993.

Renda G. (1977). Batılılaşma Döneminde Türk Resim Sanatı. Ankara 1997.

Renda G. (1986). "Göreme'de Korunması Gereken Bir Ev". AST III (1986) 103-132.

Renda G. (2002). "Yenileşme Döneminde Kültür ve Sanat". Türkler 15 (2002) 265-283.

Renda G. (2003). "Resim ve Heykel”. Eds. H. İnalcık \& G. Renda, Osmanlı Uygarlı̆̆l 2 (2003) 932-967. Ankara.

Roides S. (1985). “The Houses of Sinasos”. Sinasos in Cappadocia (1985) 113-160. Athens. 
Rubin J. H. (1979). "Pierre-Auguste Cot's the Storm”. Metropolitan Museum Journal 14 (1979) 191-193. Saner T. \& Yıldırım Z. Ö. (2006). "Sinasos Konutlarında Kentli Özellikler". Sanat Tarihi Defterleri 10 (2006) 165-179.

Stamatopoulos K. (1985). "Everyday Life in Sinasos, Cappadocia”. Sinasos in Cappadocia (1985) 39-91. Athens.

Şarlak E. \& Özer F. (2002). "Post-Bizans Döneminde İstanbul'da İkona Üreten Ressamlar ve Üslup Özellikleri”. ITÜ Dergisi 1/1 (2002) 59-68.

Şerifoğlu Ö. F. (2014). Cumhurbaşkanlığı Sanat Koleksiyonu. Ankara 2014.

Tekinalp P. Ş. (2002). “Batılılaşma Dönemi Duvar Resmi”. Türkler 15 (2002) 440-447.

Tekinalp P. Ş. (2010). "Link Between Painting and Photography in Nineteenth Century Turkey”. History of Photography 34/3 (2010) 291-299.

Vasari G. (1898). Lives of the Most Eminent Painters, Sculptors and Architects. London 1898.

Weber S. (2002). "Images of Imagined Worlds: Self-image and Worldview in the Late Ottoman Wall Painting of Damascus". Eds. J. Hansen, T. Philipp \& S. Weber, The Empire in the City. Arab Provincial Capitals in the Late Ottoman Empire (2002) 145-171. Beirut. 